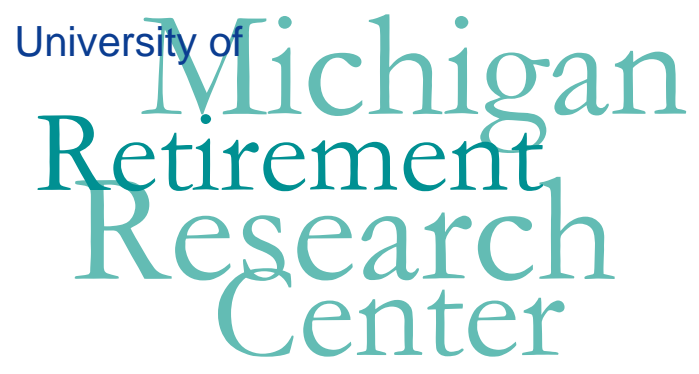

Working Paper

WP 2008-199

\title{
Saving among Low-Income Women: Motivation and Obstacles
}

Helen Levy and Kristin Seefeldt

\begin{tabular}{|l|l|}
\hline $\mathrm{M}$ & $\mathrm{R}$ \\
\hline $\mathrm{R}$ & $\mathrm{C}$ \\
\hline
\end{tabular}$\quad$ Project \#: UM08-Q3 


\title{
Saving among Low-Income Women: Motivation and Obstacles
}

\author{
Helen Levy \\ University of Michigan \\ Kristin Seefeldt \\ University of Michigan
}

September 2008

\author{
Michigan Retirement Research Center \\ University of Michigan \\ P.O. Box 1248 \\ Ann Arbor, MI 48104 \\ http://www.mrrc.isr.umich.edu/ \\ (734) 615-0422
}

\section{Acknowledgements}

This work was supported by a grant from the Social Security Administration through the Michigan Retirement Research Center (Grant \# 10-P-98362-5-04). The findings and conclusions expressed are solely those of the author and do not represent the views of the Social Security Administration, any agency of the Federal government, or the Michigan Retirement Research Center.

\section{Regents of the University of Michigan}

Julia Donovan Darrow, Ann Arbor; Laurence B. Deitch, Bingham Farms; Olivia P. Maynard, Goodrich; Rebecca McGowan, Ann Arbor; Andrea Fischer Newman, Ann Arbor; Andrew C. Richner, Grosse Pointe Park; S. Martin Taylor, Gross Pointe Farms; Katherine E. White, Ann Arbor; Mary Sue Coleman, ex officio 


\title{
Saving among Low-Income Women: Motivation and Obstacles
}

\author{
Helen Levy and Kristin Seefeldt
}

\begin{abstract}
How do low-income households think about saving? What motivations do they identify for saving, and what obstacles to meeting their goals? We use data from qualitative interviews with 51 households in Detroit to shed light on these questions. We find that they wish they could save - primarily for protection against the unexpected or to put children through college - but that most of them cannot. Friends and family surface as a major obstacle to saving, since those who have liquid assets are asked for help. When savings is feasible in this population, it occurs largely through relatively inaccessible vehicles such as pensions and 401Ks.
\end{abstract}

\section{Authors' Acknowledgements}

We gratefully acknowledge financial support from the United States Department of Agriculture, the Annie E. Casey Foundation, and the Center for Local, State and Urban Policy and the National Poverty Center at the University of Michigan. We also thank Professor Michael Barr and our dedicated team of interviewers and transcribers: Tedi Castelli, Jennifer Cecil, Benecia Cousin, Tiffany Griffin, Margaret Hudson, Maria Johnson, Casey Parrotte, Ashley Reid, Jessica Wiederspan, Jessica Wyse, and especially Sascha Demerjian. Most importantly, we thank participants in the study for sharing their experiences with us. 


\section{Introduction}

Savings rates are low for all Americans, especially for those with low incomes (Hogarth and Anguelov 2003). Current research on the relatively low rates of savings in the US struggles to distinguish between the various different motives identified by the theory (for example, precautionary versus life-cycle savings). ${ }^{1}$ But what do respondents believe their own motivations for saving to be? Do they have plans to save, or have they abandoned hope of saving? How does saving for retirement figure into their planning? If they have goals that they fail to meet, why do they fail?

In spite of a great deal of interest in understanding the determinants of savings rates, particularly for low-income households, almost no research has asked members of those households what they think is going on and how they think about saving (or not). In this paper, we use data from qualitative interviews with 51 low-income households in Detroit to shed some light on how these households think about saving, what their motives are for saving, and what obstacles they face.

We find that these households wish that they could save, and say that they plan to do so in the future when they hope to have more income. They identify many motives for saving, including the desire to have a cushion in case of the unexpected (a precautionary motive), wanting to put their children through college, saving up for a house or car. A few respondents mention wanting to start a small business. Some see this saving as complementary to retirement saving, since they plan to supplement their retirement income (which will in most cases be only what they receive from Social Security) by running a small business like a Laundromat or a catering business. Very few respondents volunteer "retirement" as a motivation for saving although when we ask specifically about retirement planning, the majority of our respondents say that they think about retirement and would like to save for it. In fact, a significant minority of our respondents are saving for retirement through either $401 \mathrm{~K}$ plans or employer-provided pensions, although the amounts in $401 \mathrm{~K}$ do not seem to be large. A number of respondents have been forced to dip into 401K savings to pay living expenses during a long unemployment spell or in order to help friends or relatives.

\footnotetext{
${ }^{1}$ Browning and Lusardi ("Household Saving: Micro Theories and Micro Facts," Journal of Economic Literature 1996 34:1797 - 1855) enumerate nine motives for saving: precautionary, life-cycle, intertemporal substitution, improvement, independence, enterprise, bequest, avarice, and downpayment.
} 
In fact, friends and family surface as a major obstacle to saving for our respondents. Those who have liquid assets are asked for help. Conversely, many of our respondents are the beneficiaries of gifts or other support (such as free housing) from friends and relatives. These complicated patterns of resource-sharing have clear benefits for the low-income population overall, providing a mechanism for smoothing consumption analogous to consumption insurance in developing economies (Townsend, 1995). At the same time, however, they imply that significant asset accumulation is unlikely unless these assets are illiquid - for example, employer-provided pensions.

The paper proceeds as follows. In the next section we describe our qualitative data collection. Section 3 discusses the results - what do respondents tell us about their motivation for saving and the obstacles that they face? We focus first on motivation and obstacles in the full sample. For the lowest-income households, many of whom are receiving public assistance, saving may never be a realistic goal; for this reason, we focus some of our discussion on the higher-income households in our sample. On the surface, these households look like they might be able to save; can they? Why or why not? Section 4 concludes with a brief discussion.

\section{Methods}

The data used in this paper come from a qualitative supplement to the Detroit Area Study on Financial Services (DAS-FS). The DAS-FS is a large-scale interview survey of 1,003 households in the Detroit area which was conducted by the University of Michigan in 2005 to obtain information on low-and-moderate income households' use of financial services. The DAS-FS sample is intended to be representative of households in relatively poor areas of Detroit, rather than all of Detroit. In particular, sample members were selected based upon a stratified random sample of the Detroit Metropolitan area, which includes Wayne, Oakland, and Macomb counties. Sample members were selected from census tracts where median household income was classified as low, moderate, or medium, relative to the median household income in Detroit. ${ }^{2}$ Households in low and moderate income census tracts were oversampled. Barr and Dokko (2006) provide additional detail on the DAS-FS.

\footnotetext{
${ }^{2}$ Survey sample members were drawn from census tracts with median incomes that are 0-60\% (“low”), 61-80\% (“moderate"), and 81-120\% (“middle”) of the Detroit area’s median income of \$49,057.
} 
For our qualitative supplement to the DAS-FS, we drew a random sample of 80 nonelderly households with children and 40 non-elderly households without children for a total of 120 households. Because the larger purpose of the qualitative supplement was to understand not just retirement but also the factors that drive use of public assistance, we oversampled households with children from the DAS-FS. Our goal was to contact respondents until we had completed 60 interviews. We expected a relatively low response rate overall both because the DAS-FS was not intended to be a panel study and because of relatively high rates of mobility among low-income households. Indeed, we encountered some difficulty locating respondents. We ultimately attempted contact with 95 DAS-FS sample members. We completed interviews with 43 of those. Of the remaining respondents whom we attempted to contact but who did not participate, almost half had moved since the time the DAS-FS survey was conducted, and we had no additional way of reaching them. Among this group, about half of the housing structures in which they lived during the survey data collection were completely abandoned. ${ }^{3}$ Another three refused to participate, three had moved out of state, two were deceased and one was a nonEnglish speaker. ${ }^{4}$ Table 1 summarizes the DAS-FS sample, our sampling frame, and the sample of interviews we completed with DAS-FS respondents.

We supplemented the DAS-FS based qualitative sample with another nine low-income single mothers who had participated in the pilot phase of this study. These pilot respondents were recruited with the cooperation of several charter schools in Detroit and one social service agency located in Washtenaw County. Thus, the total sample size for the first round of data collection, which occurred from July 2006 through March 2007, is 52 interviews. A second round of interviews was conducted in the fall of 2007 and winter of 2008. Forty-two of the 52 respondents completed a second interview; 34 of these were from the DAS sample and eight were from our pilot sample. Each interview lasts about one to three hours. Interviews are open-

\footnotetext{
${ }^{3}$ We did not make an attempt to contact all 120 people on the sub-sample list because of concerns of overrepresentation of higher income individuals. On average, higher income sample members were much easier to reach, since they tended to own their own homes or be listed in telephone directories. We analyzed the characteristics of the non-responders based on the survey data and found that compared to those in our sample, nonresponders were more likely to be married, more likely to have had a member of the household suffer a major illness or injury, more likely to report that they sometimes did not have enough to eat, and more likely to have experienced utility shut-offs. While the experiences of health shocks and utility shut-offs may indicate that the non-responders were worse off than responders, we did not find any income differences between groups.

${ }^{4}$ Inclusion into the original DAS-FS survey was meant to be contingent upon the potential respondent speaking English. Additionally, we did not have the capability of conducting the qualitative interview in other languages.
} 
ended and are structured as a conversation between the interviewer and respondent, with the interviewer bringing up topics and asking questions based on an "Interview Guide.”

Table 2 shows the average characteristics in 2005 of all DAS-FS respondents, those included in our sampling frame, and the subset with whom we completed first-round interviews. The results are broken out into subsamples with and without children because, as noted above, we oversampled households with children. In terms of age and education, our sample is reasonably representative of the population we seek to describe. Our respondents are more likely to be African-American and more likely to be female (our sample includes only one male respondent). Our respondents with children have, on average, lower income than the full DASFS sample with children, while our childless respondents have higher incomes, on average, than the full DAS-FS sample.

The data for our analysis come from the transcripts of the interviews. In particular, we focus on the following questions on saving which were included in the Interview Guide for the first round of interviews:

How do you feel about saving money for the future? Are you able to save any money?

$$
\begin{aligned}
& <\text { if yes }>\text { What are your saving strategies? } \\
& <\text { if no> Do you plan to/hope to save in the future? Why or why not? }
\end{aligned}
$$

We focus also on questions asked in the second round about saving for retirement.

Do you do any saving for retirement now?

$$
\begin{aligned}
& <\text { if yes }>\text { what and how? } \\
& <\text { if no }>\text { why not? }
\end{aligned}
$$

We also asked about whether respondents own or rent their home and whether they have a $401 \mathrm{~K}$ or pension on the job, or from a previous job for respondents who are unemployed. In addition to these questions that ask explicitly about savings, the topic of saving comes up throughout the interviews - for example, when we ask about living arrangements, respondents may say they want to buy a house and are saving for a down payment. When we ask who else lives in the household, respondents may mention a child who moved back home but is trying to save enough for his own apartment. When we discuss employment, respondents may tell us they had to use up their savings to get through a period of unemployment. The results below rely on 
an analysis of the transcript of the entire interview, not just responses to questions that are explicitly about saving.

In the discussion that follows, respondent names and some other identifying details have been changed.

\section{Results}

\section{A. How do respondents feel about saving for the future; what motives do they mention?}

Almost without exception, respondents report that saving is important and that they wish they could do it. In the words of Michelle, a 32-year old who has been unemployed for about a year and is receiving Food Stamps, "I really want to be able to save. (Laughs) I mean, I'm very good at saving, it's just I don't have the money to save, so it's hard.” Respondents also say that they plan to save more in the future; those who are unemployed say they will save when they get a job and those who are employed say they will be able to save when either their hours or their hourly wage increases. Respondents who are younger often mention that their parents have told them about the importance of saving. Their responses are consistent with models of hyperbolic discounting in which individuals plan to do better (save money, lose weight) in the future, but then the future never arrives.

Realistically, many of our respondents will not be able to save for any reason. Incomes are very low while needs are not. Forty percent of our respondents (21 out of 51) are currently receiving Food Stamps; eleven have filed for bankruptcy at some point in their lives, and many more have considered it. Nearly all have some debt, ranging from a few hundred dollars on a credit card to tens of thousands of dollars owed to utilities, cell phone and cable companies, and credit cards. What is interesting for these respondents is to consider their stated motivations for wanting to save - what is it they would save for, if they could save?

In fact, respondents identify many reasons they would like to save. These include the general desire for a "nest egg” or financial cushion against uncertainty: a precautionary saving motive. In the words of one respondent, "You have to put to the side because you never know what's gonna happen.” A number of respondents specifically mention the possibility of a car breaking down as a reason for why saving is important. Indeed, far more of our respondents mention that a car breaking down has caused problems for them because they did not have the money to fix it; one of our respondents whose financial situation is relatively stable specifically 
cites the fact that she has a reliable Toyota as one of the keys to her stability (Yvette, discussed at more length below).

Many respondents mention wanting to save to help their children with college or with other expenses, and some (like Jocelyn, who is discussed in more detail below) have actually had to dip into their own retirement savings in order to help their children. Several respondents also report that they are saving or have saved for the down-payment on a house. Interestingly, in our sample a number of very low-income respondents, including welfare recipients, own their own homes because they inherited them from family members who had owned them outright. This reflects the fact that most of our respondents are long-time residents of Detroit with family who still live in the area.

Only one of our respondents identified an independence motive for saving. Annette, 51, has been unemployed for more than a year after losing her job as a data-entry clerk - a job she had held for eleven years. Her unemployment benefits have run out and she has exhausted her savings. She is living with her boyfriend rent-free, but she does not like relying on him for financial support. Nor does she like the idea of having to rely on her children after she retires: “I've always been able to stick somethin' in the bank so when I retire. I don't wanna depend on my kids. I don't wanna hafta live with my kids or none of that. I wanna be on my own in my own place."

In some ways it is not surprising that only one of our respondents mentions an independence motive for saving. Resource-sharing is common among lower-income households (see, for example, Haider and McGarry 2006). There are many examples in our interviews that illustrate this. Our respondents are in some cases the beneficiaries and in other cases the ones providing the transfers. Indeed, it seems to us that one of the key obstacles that prevents some of our higher-income respondents from saving money is the imperative to support friends and family members, as we discuss in more detail below. And it is no accident that to the extent that our respondents have private savings for retirement, it is through pensions or 401Ks, which are either difficult or costly to tap into. We also see the flip side of the coin - members of our sample who live with relatives without paying rent, rely on friends for child care, or discuss the support their parents provided to help them avoid bankruptcy in young adulthood. 
In fact, Annette seems to be the exception that proves the rule. She is the one respondent who would like to save to be independent and also perhaps the one with the weakest support network of family and friends. Although her siblings also live in Detroit, she is not close to them:

...it's bad to say but I think we're drifting apart and I hope not, but, there's more distance between us than there has ever been... there are only three of us left now, our parents are gone and it was my mother's wish that we stay together but it's not happening...I've always been like this. I guess they call me like the black sheep...they have something and I'll be the last one to know about it. You know, I'll find out about it the day after or something...Even though I'm used to it, it does hurt.

Although a few respondents mention retirement (or, more generally, something like "when we get older") as a motivation for saving, in general respondents do not seem to think or talk about retirement saving in the same way that they think about other kind of saving. Their behavior is different too; even respondents who are completely unable to save in other ways may participate in a $401 \mathrm{~K}$ offered by their employer (and a surprising number of the employers of our very low-wage respondents make these plans available to them). Indeed, the only respondents in our sample who seem likely to have private savings when they reach retirement are those with long tenure on jobs that provide either a pension or a $401 \mathrm{~K}$, consistent with evidence showing the importance of "default" savings options (for example, Madrian and Shea 2001). In our sample of 51, ten respondents have 401Ks, including two that belong to the respondent's husband. Three more are offered a $401 \mathrm{~K}$ at work but do not participate; several more respondents mention having had them on previous jobs. Three respondents - all of them with decades of service in either government or other unions jobs - appear to expect traditional pensions. As we discuss below, saving in $401 \mathrm{Ks}$ and pensions seems to offer the best hope for respondents to accumulate assets because these vehicles are relatively protected from family and friends in need (though imperfectly so in the case of 401Ks, as we discuss below).

\section{B. Obstacles to saving: "It's always something."}

A number of obstacles to saving (besides just having a low income) emerge from our discussions with respondents. Perhaps the biggest of these is family members. In many cases, as noted above and discussed in more detail below in the cases of Yvette, Jocelyn and Edith, respondents happily provide assistance to family members in need. In other cases, though, the 
assistance is less voluntary. Consider Brenda, a fifty-year old worker in an auto plant who must hide her cash from her adult son:

"Sometimes I'll throw a couple dollars in the drawer, here and there. I got a jar; I had to hide that from its usual space, because my son was always going in it, so he hasn't found it yet. I put it in the dishwasher...I don't have to worry about him washing dishes.”

A number of our respondents have had their savings wiped out because of extended periods of unemployment. In addition to Annette, described above, there is Nicole, a very savings-oriented 27-year-old and divorced mother of one who liquidated her $401 \mathrm{~K}$ in order to pay her mortgage during a prolonged spell of unemployed. Below, we discuss several respondents who dipped into savings in order to help family members through financial difficulty.

\section{Focus on higher-income respondents}

As noted above, for respondents whose incomes are very low - for example, those who are living on welfare and/or have very unstable employment - the idea of saving any meaningful amount may be unrealistic (particularly in light of the asset limits imposed by Food Stamps and other transfer programs). But an important subset of our respondents - eleven of them - appear, at least on the surface, to enjoy the kind of economic stability that should facilitate saving. These women have stable jobs - for example, a social worker for the county, or a unionized worker in an auto plant - and some of them have husbands who stably employed as well. Household income for these respondents is between $\$ 30,000$ (for a divorced respondent) to $\$ 100,000$ (for a married respondent who has child). Can these households save? Why or why not?

Most of these respondents - seven of them - report that their overall financial situation is not too bad, using phrases like "things are going pretty well for me," "right now, it's not too bad" and "it's OK." The remaining four of these relatively high-income respondents say that they are in financial distress: "I’m broke,” "paycheck to paycheck," "a little stressful right now...honestly, we are in foreclosure," and "I'm trying to work myself out of debt." In this section, we profile three respondents from the former group and three from the latter, plus one respondent who is on the margin, with special attention to whether or not they save, how they manage to do so, or why they cannot. We begin with profiles of three relatively high-income respondents who say they are doing OK financially: Joyce, Noelia and Jocelyn. 
Even those who are materially comfortable - Yvette and Edith - have difficulty saving (except for pension) because of demands from others.

Joyce, is a single, 50-year-old woman who says she is comfortable financially. She makes $\$ 75,000$ as a public health nurse working for a county welfare agency - a job she has had for 15 years - and just bought a condominium in a new development nine months ago. She occasionally takes on additional contract nursing jobs to maintain her skills and also to provide "fun money." Although she has no children she has close relatives who live nearby (a brother, his two adult children, and an aunt) and would help her out if she needed it; they do not regularly ask her for significant financial help. One brother is an accountant and the other is a minister. Other than her mortgage, her only debt is the repayment of an educational loan for her nephew which she co-signed. She has also loaned her niece \$3,000 for her education. She does not regard this is as a burden; on the contrary, she says "I've been pleased to do it because...I have been able to do it." She saves about $\$ 12,000$ a year in a retirement fund which she considers offlimits: “I don’t even have access to that.” Joyce is one of our most financially stable respondents. The keys to her success seem to be: education in a field that is in demand (nursing); having relatives who are themselves economically self-sufficient, and prudent spending happens (she speaks disapprovingly of a friend who had to declare bankruptcy because she is a "shopaholic").

Noelia, 33, has a four-year-old daughter; she and her husband were divorced a year and a half ago. She has a college degree in marketing and a real estate license; she works as a property manager for a management company and also takes on Spanish translation work on the side (although her dream is to be a wedding planner). Her income last year was about $\$ 68,500$. She is thrifty and knows it: "I’ve always been really good at budgeting myself, so I live comfortably but I don't believe in being in debt ... I might not have like you know a \$2,000 couch but I have a nice couch.” She describes her financial situation as "stable”. She traded in her car for a smaller car to save money on gas. Her daughter already has a college savings account, to which her parents also contribute. She seems to be excellent at delaying gratification:

...if I want to go buy something, you know, I'll just tell myself no, if I save up, you know, maybe in another month, month and a half I won't have to put it on a credit card and sometimes I do but I try to pay it off at the end of the month ....if it's something that, you know, we don't need, that we just want, then you know it's kind of like put it off for a little bit, but, eventually I'll get it (laughs). 
She tries to save half of her regular paycheck and rely on the occasional income from translation for her spending money. This frugality gives her peace of mind. In contrast to her ex-husband, who has had to file for bankruptcy since their divorce, "I can actually, you know, sleep at night. (laughs) ...I can actually afford to live the life I'm living.”5 Again, the keys to her success seem to be frugality, stable employment, and few demands from friends or relatives.

Jocelyn is a married 48-year-old mother of five children. She has worked for the state as a social worker for nearly twenty years; her husband is self-employed as an insurance agent. Together, they make about $\$ 105,000$. Their expenses, however, are considerable. They have put their two oldest children through community college and the third is now a freshman at a public university. The two youngest are in high school and they are planning to send them to college as well. Their oldest son, who is 25 , has been living at home to save enough for his own apartment, and his mother expects him to move out soon. Jocelyn had saved about \$20,000 in her 401K plan but depleted those savings in order to help her older son make ends meet as he was finishing college; she now has only about $\$ 1,000$ in this account. Jocelyn expects to receive a pension from the state when she retires; she hopes to retire - by which she means leaving her career job as a social worker and opening her own business - in ten years, once her youngest child completes college. Jocelyn's relative financial success seems based on the stability of her job and her marriage, which is the longest-lasting marriage in our sample.

Next, we consider a respondent who seems to be doing OK the first time she is interviewed but who is having a harder time a year later. Yvette is a 35-year-old divorcée with four children who is a full-time sales and service rep making $\$ 48,000$ a year. Her job has health insurance benefits and a $401 \mathrm{~K}$ plan. She also receives child support of $\$ 650$ per month from the father of her two younger children. Twelve years ago she bought her current home, which had belonged to her grandmother. She also has about $\$ 10,000$ in credit card debt, which she says was not for anything "frivolous" but for necessities (gas, food) and some small home improvements (painting, carpet cleaning). This past year has been difficult for her because her mother, a nurse who has always been very supportive of Yvette, needed surgery, which was upsetting and also led her to spend extra time caring for her mother. In addition, her teenage son was in a car

\footnotetext{
${ }^{5}$ Unfortunately, we do not have second-round interview from this respondent so we do not know about her planning for retirement. She did not mention a $401 \mathrm{~K}$ at work in discussing her job during the first-round interview.
} 
accident and had legal trouble, which wiped out about $\$ 9,000$ of a $\$ 12,000$ nest egg she had

saved. She feels she is not doing as well financially as she should be:

I've really been... focusing on paying off credit card bills, getting out of debt... as far as my employment, you know, so far it's been, you know, creating a comfortable life style, so I'm not, you know, in any type of financial hardship. However, if any other unexpected events occur, it may put me in a hole. So I'm comfortable right now; however, you know, I would like to continue to pay off my credit card bills and to be able to start to save again because...[things] might come up...those events really did drain me, my savings and things.

In addition to the unusual financial stresses of the past year because of her mother's illness and her son's difficulties, Yvette faces continual requests from her extended family for financial help:

I have family who, you know, I'm the one in the family, that most of my family believe is the strongest one and the more, most stable person, and probably because I have been living here, at the same address for a number of years and have had the same telephone number the whole time. A lot of them are in situations where they're coming and going and not stable or whatever, so usually, when they get in to a financial situation or something like that, I'm probably the one that they call, and when I say cousins, you know, cousins my age. ... [they need] money to get by, whether it's for groceries for their babies or diapers or milk or you know something like that, it's usually something to help them right there immediately in their household...I mean if I have it, I'll do it and you know I've been blessed, so if I can be a blessing to somebody else, I don't have a problem with it.

When she is first interviewed, she describes her financial situation as "moderate," and as noted above says she has a "comfortable lifestyle.” By the time of her second interview, Yvette is more pessimistic about her financial situation, describing it as "very difficult," and saying "even if I end up makin' fifty thousand dollars this year, fifty thousand dollars is not enough for me to survive with four children.” She has had to refinance her mortgage and has difficulty making ends meet month-to-month. Yvette seems to be one crisis away from a financial disaster, and this appears largely in part to the misfortunes of those who depend on her - in particular, her oldest son.

Next, we consider three respondents who appear to have relatively high incomes relative to their needs, but who consider themselves to be on the brink of financial ruin: Edith, Charmaine and Rachelle. 
Edith, age 50, has worked for the Federal government for twenty years and is just a few years away from retirement; her husband is already retired from the government and receives a pension. Their household income is almost $\$ 100,000$. Edith has one 32-year-old stepdaughter, who is married with four children and lives in Georgia. In spite of this, Edith says they live "paycheck to paycheck, basically, although I make enough money to where I shouldn't have to do that.” She has about $\$ 10,000$ in credit card debt. She has refinanced her mortgage several times to pay credit card debt, which she describes as "robbing Peter to pay Paul.” When asked why it is so hard for her to make ends meet, she says, "I expect it’s expenses such as my car; my mother has Alzheimer's... my ex-sister-in-law has a very low paying job and two kids, so I'm helping another household.” She routinely provides fast-food dinners for herself and her husband, her mother, and her two "nephews" (who are in fact her ex-sister-in-law's two sons with a man who is not Edith's brother). Edith and her husband have an apartment in her basement that has been occupied by various friends and relatives. She estimates 25 different people have stayed there in the time since she bought the house 25 years ago until she got tired of it two years ago. The visitors' stays, for which they usually do not contribute anything to the household finances, have ranged from two months to two years: "it can kind of help them along until they can go get a place on their own,” according to Edith. Her former sister-in-law lives in the duplex next door, which belongs to Edith's mother, and does not consistently pay rent, although they would not consider evicting her.

In addition to the support she provides for others, Edith blames her own spending habits for preventing her from saving:

Even though I make enough money that I should be able to save, I don't. Not that I can't, I just don't... [maybe I need] a different outlook on what I spend money on...If I took away fast-food, I could save the world (laugher) with my money. If I would prepare meals, and go to the grocery store and say okay, and this dinner is going to be this day and this thing and just buy those things, I could save all the starving people in Africa... if I could cook five meals on the weekend and have it all ready, I wouldn't have to go through all of that, but I don't. Procrastination, that's the problem.

Edith and her husband should have a relatively secure retirement thanks to their government pensions, but their transfers of time and money to others have clearly undermined their ability to save for any reason. 
Charmaine is a 55-year old married woman with a fourteen year old daughter attending private school and also a 24-year-old stepson. She has a college degree in math and a graduate degree in business. Since getting married, she has worked as a teacher in a charter school; her husband is a medical technician. Although their combined income is just over $\$ 100,000$ a year, she describes her financial situation as “a little stressful.” Before her marriage (which took place when she was already in her mid-thirties) she used her pay increases on her white-collar job at an automaker to put her two nieces through private school. She does not save; she wishes she could save for her daughter's college education and also for her own retirement. She has some retirement savings in a 401K plan from the job she held before getting married; she also expects to receive a state pension from her job as a teacher. She anticipates that their household income in retirement will be about 48,000 a year, and plans to retire in three years, once their daughter is out of high school. In spite of their apparent financial stability, they were recently in foreclosure because her husband fell behind on payments (he handles this aspect of their household finances). They managed to resolve this situation, but seem close to financial hardship. Their gas was shut off over the summer and they now pay half of their bill every month. Her husband has considerable arrearage on his child support payments, although Charmaine did not specify exactly how much. She says that they have come close to running out of money for food: "it's been close - down to your last dime and then it just, Lord steps right in on time.”

It is unclear why Charmaine and her husband have such difficulty saving money. They had to file for bankruptcy about ten years ago when they both lost jobs more than once; but their current situation seems as if it ought to provide more security than they seem to enjoy. Beyond a gift of about $\$ 300$ a year to Charmaine's mother (her five siblings also contribute as much), they do not seem to support anyone outside their household, and in fact have very little interaction with their neighbors.

Rachelle has been a line cook - a union job - in a sports bar for nearly 30 years and makes about $\$ 30,000$ a year. She is divorced and has two adult children. She has a considerable amount of credit card debt. She attributes her financial difficulties to bad spending habits - as she puts it - “just not being conscious...just being foolish” and to being single:

[Saving]'s hard...it's good if you can put that kind of money aside and still manage your bills. It's hard, I think, when it's one person, trying to put money away and you are the sole survivor in your house. It's not like, okay, it's a couple 
and you all can work together. It's a big difference; to me it is - especially if you not making 30 or more a year.

Rachelle's focus is on trying to get out of debt rather than saving. Like our other relatively high-income respondents who say they are in financial difficulty (Edith and Charmaine), Rachelle will have a private pension (not a $401 \mathrm{~K}$ but an actual pension) that will supplement her Social Security income. It may be that for these respondents who do not save in spite of having incomes that seem like saving ought to be possible, pensions are a critical way to force saving.

\section{Discussion}

The most interesting lesson about savings among low-income households that emerges from our interviews is the key role that family and friends play in preventing the accumulation of assets. These same family and friends may also prevent our respondents from experiencing severe material hardship, however, when times are tough. In other words, low-income households share resources and this is a two-way street. For this reason, the best hope for savings among these households is through mechanisms that are more or less involuntary and difficult to access: pensions, and to a lesser extent $401 \mathrm{~K}$ plans. Further research on the interaction between informal resource-sharing arrangements and asset accumulation among low-income households is needed. 


\section{References}

Browning, Martin and Annamaria Lusardi. 1996. Household Saving: Micro Theories and Micro Facts. Journal of Economic Literature 34:1797 - 1855.

Haider, Steven J. and Kathleen McGarry. 2006. Recent Trends in Resource Sharing among the Poor, in Working and Poor, Rebecca Blank, Sheldon Danziger and Robert Schoeni (eds.), New York: Russell Sage.

Hogarth, Jeanne M. and Chris E. Anguelov. 2003. “Can the Poor Save?” Financial Counseling and Planning 14(1).

Madrian, Brigitte and Dennis F. Shea. 2001. The Power of Suggestion: Inertia in 401(k)

Participation and Savings Behavior. Quarterly Journal of Economics, 116: 1149-1187.

Townsend, Robert M. 1995. Consumption Insurance: An Evaluation of Risk-Bearing Systems in Low-Income Economies. The Journal of Economic Perspectives 9(3):83 - 102. 


\section{Table 1}

Sample sizes

\begin{tabular}{lrrr}
\hline & \multicolumn{2}{c}{ DAS-FS } & \multicolumn{2}{c}{ Completed first-round } \\
& 2005 sample & Our sampling frame & interviews \\
\hline$<65$, with kids & 319 & 80 & 33 \\
$<65$, no kids & 547 & 40 & 10 \\
$65+$ & 137 & 0 & 0 \\
\hline Total & 1,003 & 120 & 43 \\
\hline
\end{tabular}

Note: Our sample also includes 9 additional respondents who participated in our pilot study. 
Table 2

Respondent characteristics

DAS-FS versus our sampling frame versus our completed round 1 sample

\begin{tabular}{|c|c|c|c|c|c|c|}
\hline \multirow[b]{3}{*}{ Number of children } & \multicolumn{3}{|c|}{ Respondents with children } & \multicolumn{3}{|c|}{ Respondents without children } \\
\hline & DAS-FS & Our frame & Our sample & DAS-FS & Our frame & Uur sample \\
\hline & 2.1 & 2.1 & 2.2 & 0.0 & 0.0 & 0.0 \\
\hline Age & 35.0 & 35.8 & 35.6 & 41.1 & 41.9 & 43.4 \\
\hline Black & 0.671 & 0.675 & 0.727 & 0.669 & 0.575 & 0.800 \\
\hline White & 0.154 & 0.188 & 0.091 & 0.223 & 0.250 & 0.100 \\
\hline Other race & 0.176 & 0.138 & 0.182 & 0.108 & 0.175 & 0.100 \\
\hline Female & 0.752 & 0.825 & 1.000 & 0.561 & 0.525 & 0.900 \\
\hline Working & 0.627 & 0.675 & 0.667 & 0.574 & 0.575 & 0.800 \\
\hline If working, full-time? & 0.775 & 0.722 & 0.773 & 0.758 & 0.652 & 0.750 \\
\hline Married & 0.326 & 0.325 & 0.333 & 0.208 & 0.375 & 0.300 \\
\hline $\mathrm{Ed}<\mathrm{HS}$ & 0.278 & 0.300 & 0.303 & 0.253 & 0.225 & 0.100 \\
\hline $\mathrm{Ed}=\mathrm{HS}$ & 0.241 & 0.163 & 0.182 & 0.227 & 0.250 & 0.200 \\
\hline Some college & 0.386 & 0.425 & 0.394 & 0.382 & 0.400 & 0.400 \\
\hline College+ & 0.095 & 0.113 & 0.121 & 0.138 & 0.125 & 0.300 \\
\hline Income & $\$ 32,331$ & $\$ 29,234$ & $\$ 26,957$ & $\$ 33,170$ & $\$ 25,127$ & $\$ 29,950$ \\
\hline Income/poverty & 1.9 & 1.7 & 1.5 & 2.9 & 2.1 & 2.5 \\
\hline Missing income data & 0.163 & 0.113 & 0.061 & 0.208 & 0.225 & 0.200 \\
\hline $\mathrm{n}$ & 319 & 80 & 33 & 547 & 40 & 10 \\
\hline
\end{tabular}

